\title{
EVALUATION OF WATER USE SUSTAINABILITY IN UKRAINE
}

\author{
V. V. Grynenko \\ Y.Y. Vystavna \\ National Academy of Municipal Economy in Kharkiv, Ukraine
}

\begin{abstract}
Integrated criterion for sustainability evaluation of water use in Ukraine is developed. The criterion is based on the economic (GDP), environmental (water use, wastewater treatment) and social indicators (population, water consumption). Current situation of water use and wastewater treatment in all regions of Ukraine has been analyzed. Influences of environmental, economic and social indexes of water use sustainability for every region of Ukraine have been estimated. Critical points of water use sustainability improvement for every region have been found.
\end{abstract}

\section{KEYWORDS}

Water use; Sustainability; Environmental pollution; Social factor; Economic efficiency.

\section{INTRODUCTION}

\subsection{Premise}

Sustainable water use is required for the economic, environmental and social security of any country. Unfortunately, due to extensive use of natural resources, environmental pollution, inadequate monitoring and the lack of evaluation schemes, many developing countries face with growing crisis of environmental stability and with crisis in socio-economic roles.

\subsection{Situation and problem}

Ukraine is one of the post-soviet developing countries uses water from the biggest water basins of Europe. At present time $70 \%$ of population in Ukraine consumes water which doesn't satisfy the requirements of current sanitary conditions and none of existed water treatment technology is able to renew quality of water recourses.

Extremely difficult and strained environmental situation has been formed as a result of long intensive use of natural resources in different economic sectors and in households. There is no adequate system for evaluation of sustainability of current water use to understand the water use efficiency, to find the weak points of natural resource management and to build links between the socio-economic system, water and environment in Ukraine.

Water crisis can be stopped by developing water use strategies on local, regional and national levels, which promote both equitable access and adequate supplies [8]. It is important to develop the evaluation system based on the sustainable criteria and indicators for the situation being analyzed. 
There are different approaches to the analysis of environmental, social and economic influences on the environmental situation [2-4]. The problem is to develop integrated indicators of sustainable development and sustainability which could characterize the conditions of a territorial system in a simple form on regional and national levels.

Sustainability indicators are fragments of information which describe the conditions of a system. It is necessary to develop such criteria in order to take into account social and environmental factors on regional and national levels for the decision making process. This problem is particularly important now, when Ukraine takes active position to the EU integration and aims to achieve better quality of life and the environment.

\subsection{Objectives}

The research is focused on two main objectives. The first is to develop criteria for water use sustainability and the second is to provide the evaluation of water management on regional level in Ukraine using the proposed method.

\section{DATA USED FOR THE STUDY AND METHODS}

The official data of the National Committee of Statistics (2005) including regional GDP, water use in regions, wastewater treatment, wastewater discharges has been used in the research analysis. [9]

\section{DEVELOPMENT OF THE EVALUATION METHOD}

The aim of the research is to develop integrated criterion for evaluation of sustainability of water use on regional level. Using this criterion, it is possible to characterize the socioeconomic and environmental situation related with water use in different regions of Ukraine. The research includes social, environmental and economic factors of water use in regions of Ukraine. The main tasks are:

- Determination of social, environmental and economic efficiency of water use;

- Specification of a simulator for integrated criterion of water use sustainability on regional level,

- Evaluation of water use sustainability in the regions of Ukraine;

- Factor analysis of integrated criterion of water use sustainability; ranking regions of Ukraine by the principle of water use sustainability on the base of developed criterion;

- Preliminary analysis of economic mechanisms, which can affect water management sustainability.

The following methods have been applied for problems solving, which were put by the research: theoretical approaches into development of integrated environmental and economic indexes [5], standard methods of mathematical and economic analysis.

It is proposed to evaluate economic efficiency of water management starting from the amount of water, necessary for forming a unit of GDP of a region. Economic development can cause degradation of natural environment, as it results in the growth of energy and resources consumption [2]. Therefore, the less a region needs in water resources for forming GDP unit, the more efficient in economic sense is water management there. Thus, the criterion of economic efficiency of water management $\left(K_{i, e_{c o n}}\right)$ can be calculated as:

$$
K_{l, e c o n}=W_{l} / G D P_{1,} m^{3} / U A H
$$


Where $W_{1}$-total water consumption in the region $-i, \mathrm{~m}^{3}$;

$G D P_{I}-$ Gross domestic product of the region, money units ( $\mathrm{UAH}=0,2 \mathrm{USD}$ )

The analysis of economic efficiency illustrates the situation with quantity of water, which is used for forming GDP units into different regions of Ukraine. The results are presented in Table 1 .

Table 1. Ranking regions by the economic efficiency of water management.

\begin{tabular}{|c|c|c|c|c|}
\hline \multirow{3}{*}{ 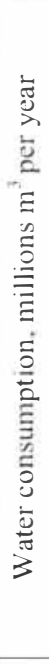 } & 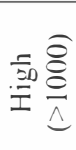 & Khersons'ka & $\begin{array}{c}\text { Crimea Republic } \\
\text { Odes'ka } \\
\text { Kijivs'ka } \\
\text { Zaporiz'ka }\end{array}$ & $\begin{array}{c}\text { Dnypropetrovs'ka } \\
\text { Donets'ka }\end{array}$ \\
\hline & 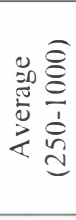 & $\begin{array}{l}\text { Kyrovograds'ka } \\
\text { Rivnens'ka } \\
\text { Chernigivs'ka } \\
\text { Cherkas'ka } \\
\text { Mykolajivs'ka } \\
\text { Sevastopol }\end{array}$ & $\begin{array}{c}\text { Poltavs'ka } \\
\text { Lugans'ka } \\
\text { Kharkivs'ka }\end{array}$ & $\begin{array}{c}\text { City Kijiv - capital of } \\
\text { Ukraine }\end{array}$ \\
\hline & $\begin{array}{l}3 \hat{\sigma} \\
0 \stackrel{n}{v} \\
\underline{v}\end{array}$ & $\begin{array}{c}\text { Zakarpats'ka } \\
\text { Ternopil's'ka } \\
\text { Chernivets'ka } \\
\text { Volyns'ka } \\
\text { Zitomirs'ka } \\
\text { Khmel'nits'ka } \\
\text { Sums'ka } \\
\text { Yvano-Frankivs'ka }\end{array}$ & $\begin{array}{l}\text { Vinnits'ka } \\
\text { L'vivs'ka }\end{array}$ & \\
\hline & & Low $(<\mathrm{I} 0000)$ & Average $(10000-25000)$ & High $(>25000)$ \\
\hline
\end{tabular}

Consequently, water use efficiency in Khersons'ka region is very low: GDP is low, but the level of water consumption is very high. Environmental and social efficiency of water use are also essential parts of evaluation of water use sustainability.

It is appropriate to define environmental efficiency of water use, as a return of treated water into natural environment. In that way, the environmental indicator of water use sustainability $\left(K_{l, c m}\right)$ can be calculated as a part of treated water in total amount of consumed water in the region.

$$
K_{l, c m v}=W_{1, t u} / W_{1} \text { non-dimensional }
$$

$W_{I, I M-}$ amount of treated water, $\mathrm{m}^{3} /$ year.

Social efficiency of water use is the most sophisticated indicator in both substantial and calculation senses. Conceptually, the social efficiency of water use is a minimization of water consumption level for the satisfactions of needs in a society. In such way, level of water consumption is closely related with water demand. It is defined, that biological need of water is about 2-5 liters of drinking water for a person per day [1]. Consumption of water in cities is 
approximately 300-600 liters per capita per day, what is higher, then in rural areas, where consumption of water is approximately 100-120 liters per capita per day. It is confirmed, that inhabitant of a big city can spend not more then 150 liters fresh water per day for full satisfaction of her/his needs [9]. The same level of water consumption can be more or less efficient in social sense with different levels of water needs. The last depends on cultural differences, environmental and climatic conditions, structure of economy, policies of a government, law and so on. It is impossible to obtain quantitative data about water needs on regional and national levels without special researches. Furthermore this data can't have high level of reliability because of the subjectivity of the term "need". Therefore, it is proposed to define social efficiency of water management as a ratio of current water consumption per person in a region to the basic or sample level of water consumption per person. Then, the problem of sample choice appears. In that case, social efficiency of water use has been calculated as a ratio of water consumption level per person in a region to the average level of water consumption level per person in Ukraine.

$$
K_{1, s o c}=W_{s} / W_{\text {shas. }} \text { non-dimensional }
$$

Where $W_{s}$ specific water consumption in a region per person, $\mathrm{m}^{3}$ per person

$W_{\text {s.bas }}$ - basic index of specific water consumption per person in a region, $\mathrm{m}^{3}$ per person.

It is proposed to integrate three mentioned indexes of water use efficiency and to calculate integrated index of water use sustainability in the following way:

$$
I_{1 . \text { sust }}=K_{l, e c o n} \times K_{l, e n n} \times K_{1, s o c}, m^{3} / U A N .
$$

The chart of integrated criterion of water use sustainability forming is presented in Figure 1.

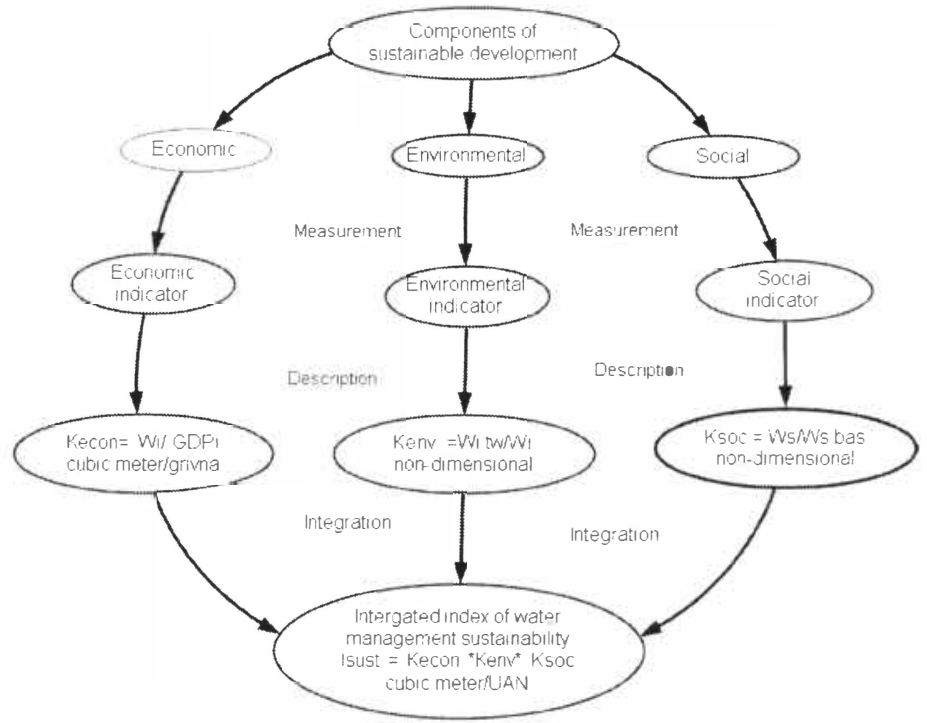

Figure 1. Forming of an integrated criterion for water use sustainability: 
The value of integrated criterion of water use sustainability has been calculated for every region of Ukraine and for the cities Kijiv and Sevastopol. The results are presented in Table 2.

Table 2. Water use sustainability into the regions of Ukraine.

\begin{tabular}{|c|c|c|c|c|}
\hline Regions of Ukraine & $\mathrm{K}_{\mathrm{soc}}$ & $K_{c n v}$ & $\mathrm{~K}_{\mathrm{ccom}}$ & $I_{\text {sust }}$ \\
\hline 1 & 2 & 3 & 4 & 5 \\
\hline Crimea Republic & 2.298 & 0.901 & 0.111 & 0.2306 \\
\hline Vinnits'ka & 0.262 & 0.707 & 0.014 & 0.0025 \\
\hline Volyns'ka & 0.284 & 0.716 & 0.014 & 0.0029 \\
\hline Dnypropetrovs'ka & 1.721 & 0.810 & 0.045 & 0.0629 \\
\hline Donets`ka & 1.588 & 0.888 & 0.039 & 0.0556 \\
\hline Zitomirs'ka & 0.293 & 0.726 & 0.016 & 0.0035 \\
\hline Zakarpats'ka & 0.158 & 0.301 & 0.009 & 0.0004 \\
\hline Zaporiz'ka & 2.005 & 0.907 & 0.059 & 0.1065 \\
\hline $\begin{array}{c}\text { Yvano- } \\
\text { Frankivs'ka }\end{array}$ & 0.256 & 0.428 & 0.012 & 0.0013 \\
\hline Kijivs’ka & 1.655 & 0.947 & 0.059 & 0.0931 \\
\hline Kyrovograds'ka & 0.412 & 0.814 & 0.020 & 0.0066 \\
\hline Lugans'ka & 0.838 & 0.832 & 0.032 & 0.0222 \\
\hline L'vivs'ka & 0.322 & 0.115 & 0.015 & 0.0006 \\
\hline Mykolajivs'ka & 0.741 & 0.853 & 0.030 & 0.0188 \\
\hline Odes`ka & 2.190 & 0.916 & 0.080 & 0.1599 \\
\hline Poltavs`ka & 0.568 & 0.784 & 0.015 & 0.0068 \\
\hline Rivnens`ka & 0.465 & 0.717 & 0.023 & 0.0078 \\
\hline Sums'ka & 0.317 & 0.721 & 0.015 & 0.0034 \\
\hline Ternopil's`ka & 0.255 & 0.686 & 0.017 & 0.0030 \\
\hline Kharkivs'ka & 0.462 & 0.372 & 0.016 & 0.0027 \\
\hline Khersons'ka & 2.212 & 0.953 & 0.121 & 0.2542 \\
\hline Khmel'nits'ka & 0.342 & 0.751 & 0.018 & 0.0047 \\
\hline Cherkas'ka & 0.676 & 0.762 & 0.031 & 0.0162 \\
\hline Chernivets'ka & 0.255 & 0.676 & 0.017 & 0.0030 \\
\hline Chernigivs'ka & 0.460 & 0.761 & 0.022 & 0.0076 \\
\hline Kïiiv & 1.094 & 0.602 & 0.012 & 0.0079 \\
\hline Sevastopol & 0.803 & 0.741 & 0.034 & 0.0202 \\
\hline
\end{tabular}

According to data, the most inefficient water use exists in the following regions: Crimea Republic, Zaporiz'ka region, Odes'ka region, Khersons'ka region. The problems of water management are related primarily with low level of people's motivation to water saving, with the absence of economic incentives to rational water consumption. One of way to improve water use efficiency is economic tools. Efficient consumption of natural resources should be economically stimulated.

Inclusions of environmental components into prices of goods and services were discussed many times by the scientists of different countries $[3,10]$. Some authors directly connect the environmental component with ecological goods and services. We have found (from the point 
of sustainable development principle and globalization of ecological problems) that it is possible to include the socio-environmental-economic component into the prices of water services. Our findings are based on the following reasons:

- not every region has the same amount of essential natural resources (water) with proper quality;

- production capacities in Ukraine are distributed unevenly, what substantially influences the level of water needs;

- the more level of urbanization in the region, the higher levels of water consumption and water pollution there;

- Price is a powerful regulator of consumption level.

The criterion of water use efficiency in a region should be accounted into prices on water supply and water treatment in order to heighten the water consumption efficiency, first of all for minimization of losses and leakages of water, introduction of water saving technologies.

There are a lot of methods to calculate the correction factor for prices on water supply and water treatment which take into consideration socio-environmental-economic efficiency of water consumption. This problem can be solved in future research activities.

As an example, the integrated criterion can be applied as a base for fixing the correction factor into the prices on water supply and water treatment. Proposed values of correction factor are presented in Table 3.

Table 3. Correction factor for economic incentives of water consumption sustainability in Ukraine.

\begin{tabular}{ccc}
\hline $\begin{array}{c}\text { Range of the integrated } \\
\text { criterion of water } \\
\text { management sustainability }\end{array}$ & $\begin{array}{c}\text { Level of water } \\
\text { management } \\
\text { sustainability }\end{array}$ & Value of correction factor \\
\hline less 0.001 & Satisfactory & 1.0 \\
\hline $0.00 d-0.0 d$ & Average & 1.001 \\
\hline $0.0 \notin-0.1$ & Unsatisfactory & 1.01 \\
\hline 0.1 and more & Critical & 1.1 \\
\hline
\end{tabular}

The indicator can be used for calculation of water supply tariff for all the groups of consumers, including civilians. The index is temporary and should be revised after every fixed term, for example every five years.

\section{RESULTS AND CONCLUSIONS}

The next summary is made as a result of the research:

- Developed criterion can be used for evaluation of water management sustainability; for analysis of social, environmental and economic influences on the level of water management sustainability and for ranking the regions by the level of sustainability.

- Criterion can be a base for development of economic stimulation mechanism in the field of water saving and water resources protection.

The perspective direction of the further development of the problem is designing the criteria of sustainability for micro level, which can be used in examination of different projects, and 
also improvement the criterion for regional and national levels including additional parameters, for instance technical.

\section{REFERENCES}

[1] Moroz, P.I., Kosenko, I.S., 2005. Ekologichni osnovy pryrodokorystuvannia - Uman (Ecological foundations of nature management - Uman) (in Ukrainian)

[2] Melnik, L.G., Schapochka M.K., 2004. Osnovy ekologiji. Ekologichna ekonomika ta upravlinnia pryrodokorystuvanniam - Sumy. Universitetska knyga (Foundations of ecology. Ecological economy and nature management - Sumy. Universitetska knyga) (in Ukrainian)

[3] Endres, A., Kverner, I., 2004. Ekonomika prirodnyh resursov - SPb.: Piter (Economy of natural recourses - SPb.: Piter) (in Russian).

[4] Pahomova, N.V., Endres, A., Rihter, K., 2003. Ekologicheskiy menegement - SPb.: Piter (Ecalogical management SPb.: Piter) (in Russian).

[5] Evdokimov, A.V., 2001. Formirovanije kriterialnoj bazy dla otsenki ekologoekonomicheskogo urovnia territorii - Sumy. Universitetska knyga (Forming of criterial base for evaluation of ecological and economic levels of a territory - Sumy. Universitetska knyga) pp. 19-24. (in Russian).

[6] Natsionalna dopovid pro yakist pytnoji vody ta stan putmogo vodopostachannia $v$ Ukrajini, 2006, - Kijiv. Ministerstvo budivnytstva, arhitektury I shilischnokomunalnogo hoziaistva v Ukrajine v 2005 r. (National report about the conditions of fresh water supply of Ukraine in 2005 - Kijiv, Ministry of building, architecture and communal services) (in Ukrainian).

[7] www.menr.gov.ua - Website of the Ministry of ecology and environment protection of Ukraine (in Ukrainian).

[8] www.Enmilleniumproject.org/goals - Millenium Development Goals

[9] www.ukrstat.gov.ua - Website of the State committee of statistics of Ukraine (in Ukrainian).

[10] Bernd Heinzmann. Measures to minimize water consumption and water losses - case study of Berlin//Proceedings of the Seminar organized by the Regional Centre on Urban Water Management. Technical Documents in Hydrology No. 79, UNESCO, Paris, 2006. - pp. 48-58.

[10] Neil. S. Grigg. Water Resource Management. Principles, Regulations and Cases. McGraw-Hill, - New York, - 1996. - 540 p. 